\title{
Pachymeningeal enhancement in baroreflex failure syndrome
}

Figure MRI brain

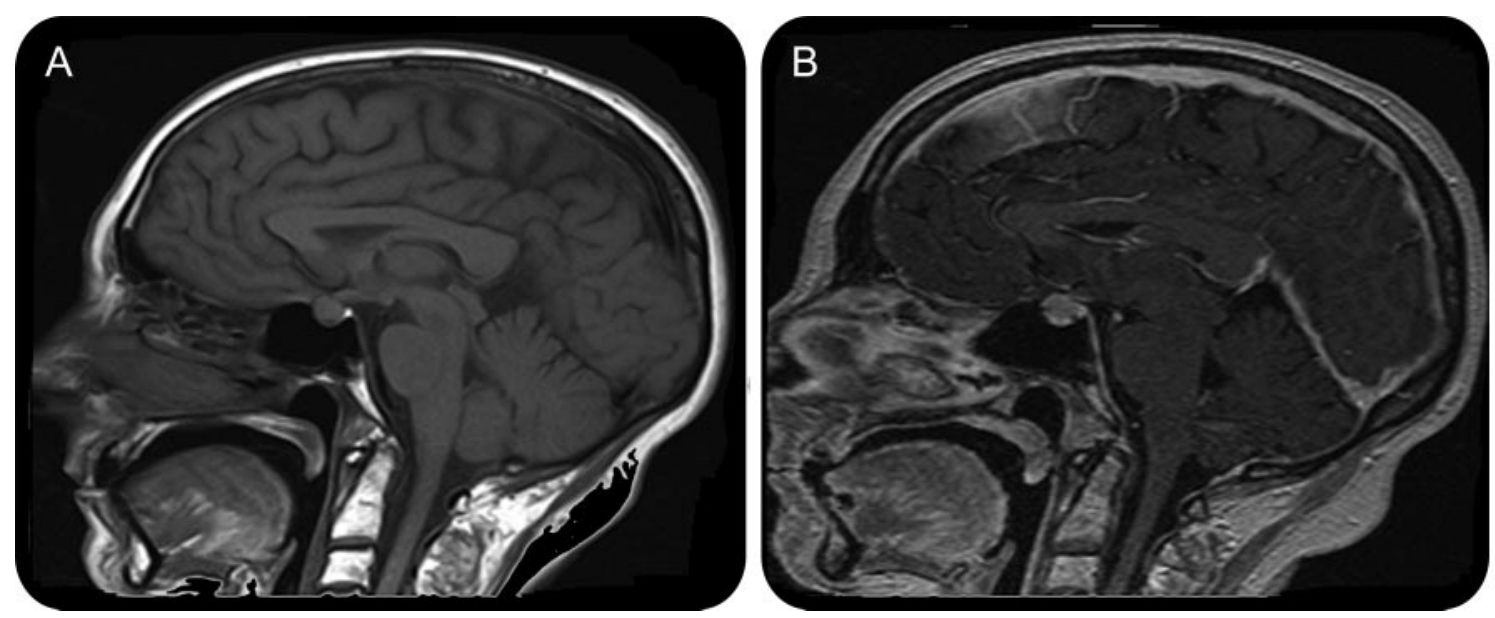

MRI brain T1 sagittal views without (A) and with (B) gadolinium showing notable pachymeningeal enhancement. Carcinomatosis was a consideration, but normal neurologic examination and 8 symptom-free years after initial cancer diagnosis suggest this is unlikely. Repeat brain MRI (not shown) 10 months later showed no change in enhancement.

A 64-year-old woman developed baroreceptor reflex failure 3 years following radiation to the neck for metastatic squamous cell carcinoma. Blood pressures (BP) ranged from 70/40 to 240/140 mm Hg. MRI of brain demonstrated pachymeningeal enhancement (figure). The patient declined lumbar puncture. Baroreceptor denervation may occur after neck radiotherapy, bilateral carotid body resection, and bilateral carotid endarterectomy. ${ }^{1}$ Dramatic fluctuations in the patient's BP cause changes in cerebral blood volume, CSF volume, and cerebral venous pressure, resulting in pachymeningeal enhancement. The Monro-Kellie hypothesis supports this: the sum of volumes of brain, CSF, and intracranial blood is constant; an increase in one causes decrease in the remaining two. ${ }^{2}$

Christina Fournier, $M D,{ }^{*}$ Jayashri Srinivasan, MBBS, PhD, * Burlington, $M A$

*These authors contributed equally to this work.

Disclosure: The authors report no disclosures.

Address correspondence and reprint requests to Dr. Jayashri Srinivasan, Lahey Clinic, 41 Mall Road, Burlington, MA 01805; jayashri_srinivasan@lahey.org

1. Robertson D, Hollister AS, Biaggioni I, Netterville JL, Mosqueda-Garcia R, Robertson RM. The diagnosis and treatment of baroreflex failure. N Engl J Med 1993;329:1449-1455.

2. Mokri B. The Monro-Kellie hypothesis: application in CSF volume depletion. Neurology 2001;56:1746-1748. 


\section{Neurology}

\section{Pachymeningeal enhancement in baroreflex failure syndrome \\ Christina Fournier and Jayashri Srinivasan \\ Neurology 2010;75;375 \\ DOI 10.1212/WNL.0b013e3181ea1625}

This information is current as of July 26, 2010

\section{Updated Information \& Services}

References

Subspecialty Collections

Permissions \& Licensing

Reprints including high resolution figures, can be found at: http://n.neurology.org/content/75/4/375.full

This article cites 2 articles, 1 of which you can access for free at: http://n.neurology.org/content/75/4/375.full\#ref-list-1

This article, along with others on similar topics, appears in the following collection(s):

Autonomic diseases

http://n.neurology.org/cgi/collection/autonomic_diseases MRI

http://n.neurology.org/cgi/collection/mri

Information about reproducing this article in parts (figures,tables) or in its entirety can be found online at:

http://www.neurology.org/about/about_the_journal\#permissions

Information about ordering reprints can be found online:

http://n.neurology.org/subscribers/advertise

Neurology ${ }^{\circledR}$ is the official journal of the American Academy of Neurology. Published continuously since 1951, it is now a weekly with 48 issues per year. Copyright. All rights reserved. Print ISSN: 0028-3878. Online ISSN: 1526-632X.

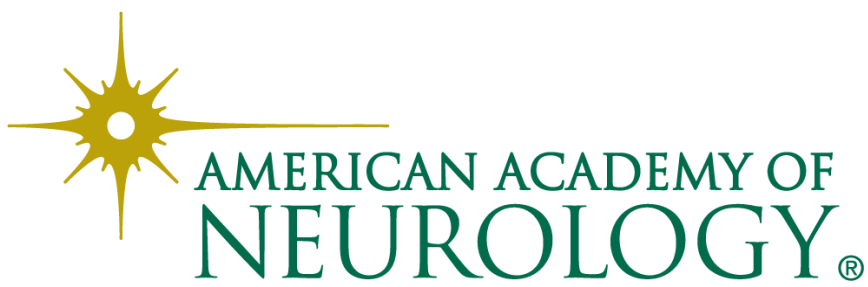

